\title{
A falência seletiva do Plano Diretor de Fortaleza
}

\author{
The selective failure of Fortaleza's Master Plan
}

Marcelo Mota Capasso [I]

Renato Pequeno [II]

\section{Resumo}

Fortaleza aprovou seu Plano Diretor Participativo (PDP) em 2009 orientado a uma agenda urbana progressista. Mas uma década de vigência deixou evidente a retomada da agenda urbana pelo setor imobiliário: alterações ao plano potencializaram vantagens para a construção civil em áreas estratégicas à captura da valorização do solo, especialmente onde há interesse privado na verticalização, ao passo que se inviabilizaram avanços na inclusão territorial e proteção do patrimônio cultural edificado. A falência seletiva do PDP remonta às contradições de sua implementação, apoiada em novas regulações mercantilizadoras do espaço urbano. Dessa forma, apresentamos as estratégias do novo ajuste do marco regulatório do planejamento às demandas do capital imobiliário, utilizando a categoria "deregulated regulation" proposta por Aalbers (2016).

Palavras-chave: Fortaleza; planejamento urbano; plano diretor; verticalização; zoneamento.

\begin{abstract}
The city of Fortaleza (Northeastern Brazil) enacted a Participatory Master Plan (PMP) in 2009, targeted at a progressive urban agenda. However, after a 10-year term, the resumption of the urban agenda by the real state sector became evident: amendments to the Plan have enhanced advantages to civil construction in strategic areas for land value increase, especially where there is private interest in high-rise building development. In addition, such amendments have had negative effects on social inclusion in the city and on the protection of urban landmarks. PMP's asymmetrical regulatory failure is related to contradictions in its enforcement, supported by new regulations for urban space commodification. We present, in this article, the strategies that adjusted the legal framework of urban planning to the demands of real estate capital, using the category "deregulated regulation" proposed by Aalbers (2016).
\end{abstract}

Keywords: Fortaleza; urban planning; master plan; high-rise building development; zoning. 


\section{Introdução}

O município de Fortaleza anunciou, em 2019, a revisão de seu Plano Diretor Participativo (PDP-2009), formando um núcleo gestor para a coordenação do processo. Apesar de a revisão decenal do plano diretor ser uma exigência do Estatuto da Cidade (Brasil, 2008), permanecem sem regulamentação definitiva vários instrumentos progressistas assimilados ao PDP: de combate à especulação imobiliária, de inclusão territorial, de proteção ao entorno de bens tombados, de gestão democrática, etc. Durante a década de vigência, alterações no zoneamento do PDP, especificamente seus parâmetros de ocupação do solo, cada vez mais permissivos a demandas de mercado, em clara oposição a princípios e objetivos elencados no plano, motivaram-nos preocupação relacionada ao aprofundamento da segregação socioespacial.

O PDP foi aprovado em um contexto político nacional e local favorável à inclusão da agenda progressista no planejamento urbano. O próprio Estatuto da Cidade reforçou o plano diretor como "o instrumento básico da política de desenvolvimento e expansão urbana". O plano assumiu protagonismo como meio de atingir um conjunto de demandas históricas da urbanização brasileira, concatenando o projeto utópico da reforma urbana. Motivou movimentos sociais, que, inclusive, punham questionamentos acerca da legítima participação social na elaboração. A criação e atuação do Ministério das Cidades contribuíram, ainda, muito para o avanço da agenda. Em 2005, o próprio Ministério promoveu ampla campanha nacional pela revisão participativa dos planos (Campanha Plano Diretor Participativo - Cidade de Todos), para que municípios afetados pela exigência da elaboração a cumprissem até outubro de 2006, aniversário de 5 anos do Estatuto.

Fortaleza extrapolou o prazo, levando mais 3 anos para concluir o documento do PDP, resultando em um plano diretor com grandes promessas de realização. Movimentos sociais já vinham se fortalecendo criticamente sobre a relação entre especulação imobiliária e exclusão territorial, discussão fomentada sob forte articulação com ONGs e setores progressistas da universidade pública, desde a aprovação do Estatuto da Cidade em 2001. Reconheciam a pertinência dos instrumentos do Estatuto "como estratégias de combate à especulação imobiliária e promoção de regularização fundiária" (Freitas e Pequeno, 2012, p. 491).

Apesar de Fortaleza ter iniciado a revisão sob a égide do Estatuto em 2002, diversos questionamentos dos movimentos acerca da participação popular na elaboração do novo plano diretor, meramente consultiva, levaram à sua interrupção em 2005. 0 próprio Executivo local retirou o projeto de lei já havia sido enviado à Câmara; e o processo foi retomado em 2006 sob nova orientação política e com nova equipe. ${ }^{1}$ Houve inovações, como a inclusão dos parâmetros gerais de zoneamento já na lei do PDP, além da delimitação de Zonas Especiais de Interesse Social (Zeis), fruto da abertura à deliberação popular. Essa "antecipação" de normas fundamentais no conteúdo era uma das principais recomendações da Campanha Plano Diretor Participativo - Cidade de Todos, visando a coibir uma lei somente de objetivos e princípios, ou seja, um "plano-discurso", aspecto denunciado categoricamente por Villaça (2005), ao falar da inefetividade histórica do plano diretor. Para ir além de 
simples formalidade a cumprir pelo Executivo, já deveria se estabelecer, ao contrário, como um "plano-ação" (Gomes, 2006). Comentando a importância da antecipação de conteúdo no plano, Gomes afirma que:

Não há como delimitar, em caráter prévio e geral, o conteúdo adequado para o Plano Diretor. Por se tratar de uma lei inicial sobre o desenvolvimento urbano, assunto a ser desmembrado e pormenorizado em outras leis, aparece sempre a questão sobre o que merece ser antecipado por ele e sobre o que é mais conveniente ficar para um segundo momento. Na prática, a ascendência do Plano Diretor sobre a legislação local costuma atrair determinadas questões para aquele Diploma Legal, pois tal inclusão, além de conferir status, propicia maior estabilidade para o tratamento desejado. A abertura para participação popular potencializa ainda mais a diversidade de temas. (Ibid., p. 102; grifos nossos)

Assim, a inclusão dos parâmetros de zoneamento tornou-se uma das grandes novidades no PDP. Isso abria um contraponto ao Plano Diretor de Desenvolvimento Urbano de Fortaleza (PDDU-FOR/1992), cujos parâmetros de zoneamento só haviam sido definidos a posteriori, na Lei de Uso e Ocupação do Solo de 1996, fruto de uma consultoria de escritório, sem participação de setores populares. Dessa forma, a menção a zeis no diagnóstico do PDDU-FOR não passou de formalidade, não tendo havido delimitação em planta urbana. Somente por ocasião do PDP é que as zeis foram finalmente delimitadas, contando com forte pressão dos movimentos sociais (Freitas e Pequeno, 2012). Houve ganho também em outros assuntos, com a instituição de zoneamento especial para o patrimônio cultural, as ZEPH (Zonas Especiais de Preservação do Patrimônio Paisagístico, Histórico, Cultural e Arqueológico), que contemplariam a normatização do uso e ocupação do solo no entorno de bens tombados.

Entretanto, apesar das disposições finais do PDP indicarem a urgência da regulamentação em leis específicas, tanto da habitação de interesse social, quanto das ZEPH e do ConseIho da Cidade, tais pautas obtiveram ganhos assimétricos até 2020, menos significativos quando comparados às crescentes vantagens de mercado.

\section{Metodologia}

O período de 2009 a 2020 permitiu vislumbrar um recuo contundente na agenda progressista. Apesar da aguardada implementação gradativa, poucas normas associadas à regulamentação dos novos instrumentos vingaram. Estaríamos mais uma vez diante de um "plano-discurso"? Na verdade, a questão revela uma contradição a ser explorada: o PDP funcionou sim, mas em um campo assimétrico de forças, aumentando a distância entre princípios e objetivos, de um lado, e, de outro, suas normas eminentemente técnicas. Tais normas são os parâmetros de zoneamento que regulam o uso e a ocupação do solo, que exatamente o operacionalizam enquanto plano-ação.

Dessa forma, a análise integra pesquisa em âmbito maior sobre a falência seletiva do $P D P$, a partir de três importantes constatações: 1) a antecipação de grande parte dos parâmetros de zoneamento, incorporados ao texto final do PDP, foi um contraponto à prática 
de confiá-los à lei de uso e ocupação do solo, tendo permitido maior controle social sobre sua definição; 2) as alterações de zoneamento, tanto na aprovação na Câmara, quanto na vigência do PDP, permitem divisar uma recuperação do controle político da agenda urbana pelo setor imobiliário; 3) o deslocamento do campo de forças em favor do setor imobiliário avança no período de vigência do PDP, sendo a permanência de organizações pouco representativas das pautas populares nos órgãos colegiados de planejamento urbano um importante indicador, associado ao abandono da regulamentação do Conselho da Cidade.

Quanto ao aspecto espacial, optamos, neste artigo, por trabalhar a relação entre a intensidade da verticalização e as demandas regulatórias do mercado imobiliário expressas nas alterações de parâmetros de zoneamento, destacando os empreendimentos residenciais multifamiliares. As demandas regulatórias refletem-se nas revisões do padrão de controle urbano da produção de edifícios, quase sempre orientadas a áreas de interesse do mercado imobiliário residencial de alto padrão, atingindo princípios e objetivos do zoneamento do PDP. Logo, prosseguimos a análise sob a categoria "regulated deregulation" proposta por Aalbers (2016), traduzida como regulação para desregulamentação (Lage et al., 2018). Abdicamos da questão "se o plano diretor funciona", orientando-nos, de outro modo, a "como o plano diretor funciona". Assim, evitamos tomá-lo em caráter apriorístico, como se fosse "documento fechado", autoaplicável e independente das disputas em torno de sua implementação. É nessa fase, afinal, que instrumentos importantes do PDP foram obliterados, e seus objetivos, desregulamentados em favor de uma nova regulação de parâmetros de zoneamento de ocupação do solo, resposta a demandas materiais de agentes privados envolvidos na produção do espaço urbano.

Por fim, para avaliar o estado da arte do zoneamento, consideramos três níveis de regulação diferenciados para as zonas, em relação a seus parâmetros: 1) instituição: referindo-se à zona já constante na lei, mas sem delimitação nem regras de índice de aproveitamento (I.A.), nem altura máxima edificável; 2) delimitação: quanto à zona que apresenta pelo menos espacialização conhecida, constituindo uma poligonal; 3) regulamentação: quanto à zona que já possui suas regras particulares de parâmetros urbanísticos (I.A. e altura máxima), ou seja, com regulação própria das características dos edifícios. Tal sistematização ajudou a revelar que o zoneamento especial de caráter progressista é o que alcançou menor nível de regulação até 2020 . Apesar de a classificação do zoneamento especial ser um pouco mais rebuscada no PDP, selecionamos apenas zeis, ZEPH e zedus (Zonas Especiais de Dinamização Urbanística e Socioeconômica) para uma análise comparada, por já serem suficientemente elucidativas do problema.

\section{A regulação do zoneamento}

É pelo zoneamento que se impõem limitações urbanísticas à propriedade urbana, já que, aprovado antecipadamente no plano diretor, regula o adensamento construtivo e populacional, dando parâmetros à construção de edifícios. Meireles (2008, p. 529) argumenta que "os superiores interesses da comunidade justificam as limitações urbanísticas de toda ordem, notadamente sobre área edificável, altura 
e estilo dos edifícios, volume e estrutura das construções". Esse ponto de vista se alinha à sua visão de urbanismo - o conjunto das ações planejadas sobre o espaço urbano - como um "sistema de cooperação" e "expressão do desejo coletivo", em prol do bem-estar humano.

A escolha dos parâmetros de ocupação do solo - em tese - é resultado da avaliação das condições de infraestrutura, como drenagem, transporte e lotes disponíveis para edificação. Castilho (2010, p. 167) destaca que o zoneamento de ocupação do solo "atende antes imperativos de ordem técnica: a capacidade da infraestrutura para suportar o adensamento construtivo". 0 adensamento construtivo regula-se pelo I.A. e altura máxima, diferenciados por zona, limitando o volume edificado. Já a fração do lote é um parâmetro mais objetivo de controle do adensamento populacional, ao balizar o número de unidades habitacionais por empreendimento. Assim, I.A., altura máxima e fração do lote regulam tanto o direito de construir (potencial construtivo gratuito), quanto a outorga onerosa do direito de construir (potencial construtivo adicional, pago) na legislação urbanística brasileira.

No caso de Fortaleza, o zoneamento desdobra-se em zonas orientadas ao controle diferenciado do adensamento, a partir da oposição entre áreas muito adensáveis e áreas pouco ou não adensáveis. Os critérios utilizados apontam tanto para a proteção ambiental, como para a disponibilidade de infraestrutura, tendo sido o município dividido em Macrozona de Ocupação Urbana e Macrozona de Proteção Ambiental, cujas Zonas ${ }^{2}$ têm características específicas, informadas no Quadro 1.

A Macrozona de Proteção Ambiental, por conter as zonas ambientalmente frágeis, teria maiores limitações, com I.A. e altura máxima mais baixos. Mas as ZIAs Praia do Futuro e Cocó, áreas de campos de dunas ou de amortecimento ambiental, parcialmente ocupadas antes de 2009, foram aprovadas no PDP com parâmetros muito similares a áreas já consolidadas, caso emblemático do alcance da contradição aqui discutida. Já quanto aos objetivos propostos na Macrozona de Ocupação Urbana, planejou-se o equilíbrio entre infraestrutura disponível e subutilização imobiliária, densidade e futuros investimentos públicos em urbanização.

Assim, pelas limitações urbanísticas, estão em extremos opostos as duas ZOPs, mais permissivas, e a ZOR, mais restritiva. 0 principal estímulo a investimentos imobiliários, especialmente de verticalização intensiva, foi dado às primeiras, pelo maior I.A. básico do município. As ZOPs foram caracterizadas, no PDP, com alto nível relativo de infraestrutura e equipamentos públicos e alta subutilização de imóveis, portanto, recebendo os parâmetros mais permissivos já no projeto de lei enviado à Câmara. Além disso, a ZOR teria suas glebas "reservadas", proibindo o parcelamento, mas permitindo investimentos públicos de infraestrutura e equipamentos em áreas já loteadas. Porém, ao analisar a terceira fase de implantação do Programa Minha Casa Minha Vida em Fortaleza, Pequeno e Rosa (2016) já denunciavam a falência seletiva do PDP e seu zoneamento, apontando que:

[...] buscando cumprir promessas de campanha, a PMF [Prefeitura Municipal de Fortaleza] partiu para a aprovação de grandes conjuntos num setor da cidade considerado como Zona de Ocupação Restrita (ZOR), onde as recomendações são contrárias ao tipo de empreendimento. Controlar e inibir a ocupação 
Quadro 1 - Zonas do PDP e suas características

\begin{tabular}{|c|c|c|}
\hline Macrozona & Zonas & Características \\
\hline \multirow{3}{*}{$\begin{array}{l}\text { Proteção } \\
\text { Ambiental }\end{array}$} & $\begin{array}{l}\text { Zona de Preservação Ambiental } \\
\text { (ZPA) }\end{array}$ & Equivalem às mais restritivas à ocupação. \\
\hline & $\begin{array}{l}\text { Zona de Interesse Ambiental } \\
\text { (ZIA) }\end{array}$ & $\begin{array}{l}\text { Áreas ambientalmente frágeis com ocupação em consolida- } \\
\text { ção, sem risco. }\end{array}$ \\
\hline & $\begin{array}{l}\text { Zona de Recuperação Ambiental } \\
\text { (ZRA) }\end{array}$ & Áreas de amortecimento ambiental. \\
\hline \multirow{6}{*}{$\begin{array}{l}\text { Ocupação } \\
\text { Urbana }\end{array}$} & $\begin{array}{l}\text { Zona de Ocupação Restrita } \\
\text { (ZOR) }\end{array}$ & $\begin{array}{l}\text { Tem predomínio de glebas não parceladas, objetivando } \\
\text { coibir expansão urbana. }\end{array}$ \\
\hline & Zona de Orla (ZO) & $\begin{array}{l}\text { Exigem parâmetros específicos pelos aspectos paisagísticos } \\
\text { e turísticos; muitas vezes tratadas como áreas de amorteci- } \\
\text { mento ambiental, mas, em alguns trechos, são altamente } \\
\text { permissivas. }\end{array}$ \\
\hline & $\begin{array}{l}\text { Zona de Ocupação Moderada } \\
\text { (ZOM) }\end{array}$ & $\begin{array}{l}\text { Insuficientes em infraestrutura, sua ocupação condiciona-se } \\
\text { à ampliação do sistema de mobilidade e de esgoto; equivale } \\
\text { à área de expansão do mercado imobiliário de alto e médio } \\
\text { padrão }\end{array}$ \\
\hline & $\begin{array}{l}\text { Zona de Requalificação Urbana } \\
\text { (ZRU) }\end{array}$ & $\begin{array}{l}\text { Insuficiente em infraestrutura, com grande incidência de } \\
\text { assentamentos precários. Sua ocupação condiciona-se a } \\
\text { investimentos em infraestrutura, além de se orientar ao } \\
\text { mercado popular. }\end{array}$ \\
\hline & $\begin{array}{l}\text { Zona de Ocupação Consolidada } \\
\text { (ZOC) }\end{array}$ & $\begin{array}{l}\text { Com focos de saturação da infraestrutura, objetiva a } \\
\text { contenção da ocupação intensiva do solo e a recuperação } \\
\text { da valorização imobiliária para a coletividade. Zona com } \\
\text { segunda maior quantidade de bens tombados e classifica- } \\
\text { dos, também concentra a maior parte da verticalização de } \\
\text { alto padrão. }\end{array}$ \\
\hline & $\begin{array}{l}\text { Zona de Ocupação Preferencial } \\
\text { (ZOP) }\end{array}$ & $\begin{array}{l}\text { Destacam-se pela infraestrutura e pelos serviços urbanos, } \\
\text { mas com subutilização imobiliária, destinando-se a intensifi- } \\
\text { cação e dinamização do uso e ocupação do solo }\end{array}$ \\
\hline
\end{tabular}


dessas áreas devido às condições esparsas de ocupação e às carências de infraestrutura e serviços, apesar de apontadas no plano diretor, não conseguem impedir a aprovação desses novos grandes conjuntos. (p. 210)

Quanto às ZOs, apesar de área urbana consolidada, seus objetivos apontavam ao amortecimento ambiental da faixa de praia. Porém, várias ZOs ganharam parâmetros bem permissivos já na aprovação do PDP. Da mesma forma, a ZOC, caracterizada "com focos de saturação da infraestrutura, destinando-se à contenção do processo de ocupação intensiva do solo" (lei complementar 62, 2009), recebeu indicadores elevados. Na aprovação do plano na Câmara já se revelava uma incongruência entre princípios e objetivos, de um lado, e parâmetros urbanísticos, de outro. Sofreram emendas de ampliação de I.A., já durante a discussão do projeto de lei na Câmara Municipal, tanto as ZO2, ZO3, ZO4, ZO5, ZO7, ZIA Cocó, ZIA Praia do Futuro, quanto a ZOC e a ZOM1. ${ }^{3}$ Sobre a interferência do setor imobiliário na aprovação do PDP, Rufino relembra que:

A atuação da Câmara foi decisiva na descaracterização do plano, com a modificação dos índices de adensamento construtivo e de verticalização que privilegiaram os interesses do mercado imobiliário. Ao compararmos a versão enviada à Câmara com a versão final aprovada, constatamos que as zonas que sofreram ampliação dos índices urbanísticos correspondem justamente às áreas da produção imobiliária intensiva de alto padrão. (Rufino, 2016, p. 298)

Já na vigência do PDP o número de alterações no zoneamento foi proporcional ao enfraquecimento da agenda progressista: 61 no total, até 31 de janeiro de 2020, algumas cumulativas sobre os mesmos recortes espaciais. Das 61, 27 foram emendas sobre limites ou parâmetros das Zonas; 7 reeditaram regras das zonas especiais delimitadas em 2009, especialmente critérios de regularização fundiária em zeis; outras 29 trataram da regulamentação de novo zoneamento especial, definindo poligonais e parâmetros que não constavam do PDP. Uma das alterações tratou da extinção da fração do lote na ZOC, ZOP1 e ZOP2 (lei complementar 243, 2017). 4 das emendas citadas caracterizaram-se pela grande extensão territorial, alterando limites da Macrozona de Proteção Ambiental (leis complementares 101, 2011; 202, 2015; 236, 2017; e 250, 2017). As demais alterações deram-se sobre porções territoriais mais restritas, tendo 19 aumentado o I.A. bás.; 27 , a altura máxima; e 18 , o coeficiente de outorga onerosa (diferença entre IA. bás. e I.A. máx.), tanto por transposição de limites de Zona, quanto por novo zoneamento especial. ${ }^{4} \mathrm{~A}$ nova área útil, relacionada a cada um dos três parâmetros ampliados, foi respectivamente de 1436 ha, 1939 ha e 1567 ha. Ao todo, até 2020, a área com parâmetros aumentados decorrente de emendas às Zonas foi de 1673 ha; a de regulamentação de zedus sem emendas posteriores, 953 ha; e a de emendas às zedus, 200 ha - totalizando 2826 ha.

Das 18 alterações de zoneamento aumentando o coeficiente de outorga onerosa, 16 deram-se exatamente após a regulamentação desse dispositivo pelas leis ordinárias n. 10.335/2015 e n. 10.431/2015. A outorga ancora parte de sua legitimidade na cobrança feita ao incorporador, ao se transformar em receita municipal, e, no caso de Fortaleza, também na aprovação expedida por órgão colegiado meramente consultivo, 
Figura 1 - Tipos de alteração ao zoneamento com aumento de coeficientes (I.A. bás./ I.A. máx./ altura máxima) na vigência do PDP até 31/1/2020, em Fortaleza

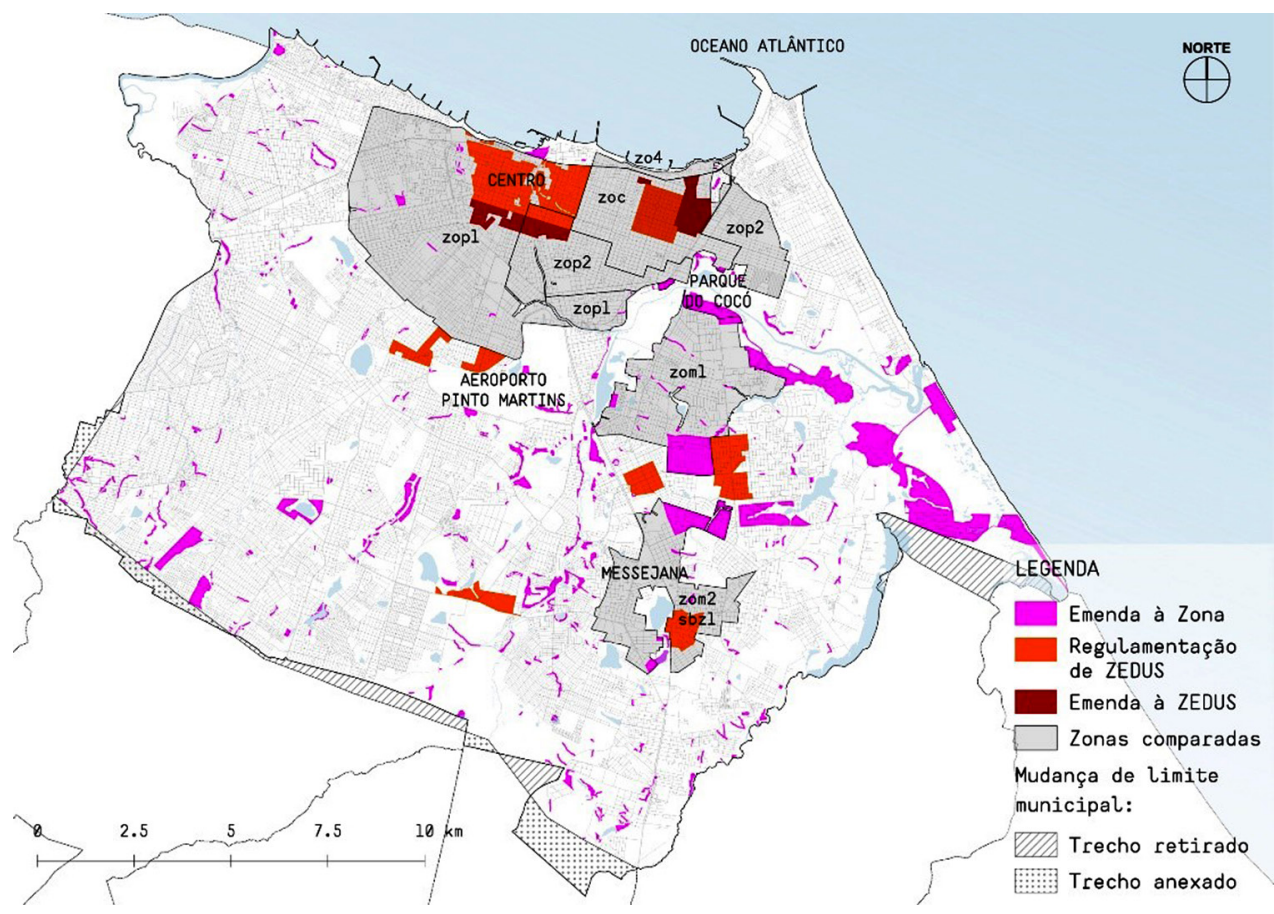

Fonte: organizado por Isabelle Almeida e Marcelo Capasso. Acervo LEHAB-UFC.

regulamentado em 1995, na vigência do plano diretor anterior, estranhamente ainda ativo: a Comissão Permanente de Avaliação do Plano Diretor (CPPD). O avanço espacial da outorga onerosa em Fortaleza foi de forma tal, que a Lei de Uso e Ocupação do Solo (lei complementar 236, 2017) modificou parâmetros através da regulamentação de zedus, permitindo sua cobrança em dez setores da Macrozona de Ocupação Urbana. Como o zoneamento especial em Fortaleza funciona por sobreposição ao macrozoneamento, através das zedus foi liberada outorga em extensas áreas da ZOC e da ZOM2, contrariando princípios e objetivos do PDP. A zedus foi importante no respaldo legal da verticalização por outorga onerosa, legitimando sua aplicação em áreas estratégicas de mercado. Antes, a aprovação pela CPPD de empreendimentos classificados como "projeto especial" apenas se dava como um "contract zoning", o que segundo Cullingworth (2005) é: 
[...] the rezoning of a property subject to conditions. Typically, the conditions are negotiated between the owner and the local government following a specific proposal by the owner. There is much learned discourse on the validity and the desirability of conditional rezoning. The argument in favor holds that conditions can render acceptable a use which otherwise would be unacceptable. The contrary argument is that the police power cannot be subject to bargaining, that conditional rezoning is illegal spot zoning, and that local governments have no power to enact conditional zoning amendments. (p. 62; grifo nosso)
Ou seja, o "projeto especial" trata-se de rezoneamento do lote, a partir de uma demanda direta do empreendedor, que tenha interesse em edificar além das limitações urbanísticas, mas garantindo alguma contrapartida ao Município. O "contract zoning" torna-se problemático pela definição local de "projeto especial" envolver também habitação verticalizada de alto padrão. Argumentos em defesa dos empreendimentos, em diversas atas da CPPD, versam sobre promoção do desenvolvimento, manutenção da receita municipal e até um "novo ícone para Fortaleza". Porém, não se esclarece como esse tipo de empreendimento

Figura 2 - Aumento do I.A. bás. na vigência do PDP até 31/1/2020, em Fortaleza

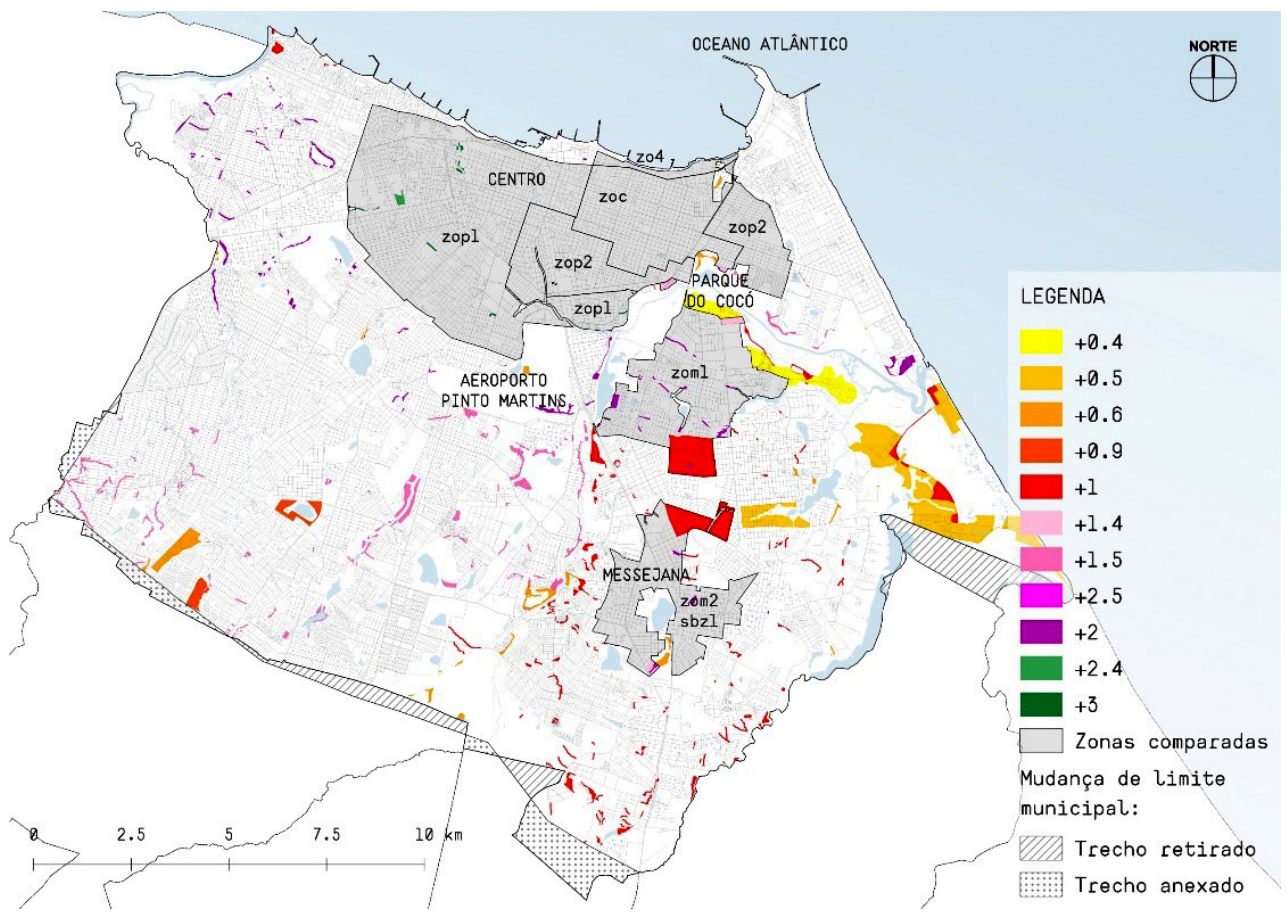

Fonte: organizado por Isabelle Almeida e Marcelo Capasso. Acervo LEHAB-UFC. 
é uma expressão do desejo coletivo (aqui retomando Meirelles, 2008) em prol do bem-estar humano, que justifique tal desregulamentação, o que nos sugere um franco "spot zoning". Lage et al. (2018) mapearam a localização dos edifícios aprovados, após o PDP, utilizando-se de potencial construtivo além do teto instituído pelo plano para todo o município (I.A. máx. 4): enquanto, em 2009, eles se concentravam na ZOP2, ZOM1 e ZOM2; em 2015, já estavam na ZOC, ZOP1, ZRU2 e em quase todas as ZOs, sem atenção a seus princípios e objetivos. Os empreendimentos foram, em grande parte, habitação de alto padrão, verticalizada acima dos limites estabelecidos na Zona - I.A. máx. e altura máxima, e até recuos, taxas de ocupação e permeabilidade.

As regras de zoneamento revelaram-se objeto de preocupação na vigência do PDP, e suas alterações representam uma enorme contradição aos objetivos do plano, apontando à mercantilização do espaço urbano (Brasil, Capasso e Cavalcanti, 2017). Evidenciaram a relação da desregulamentação em processo com as novas regulações estratégicas à contínua produção imobiliária residencial de mercado.

Figura 3 - Aumento do coeficiente de outorga na vigência do PDP até 31/1/2020, em Fortaleza

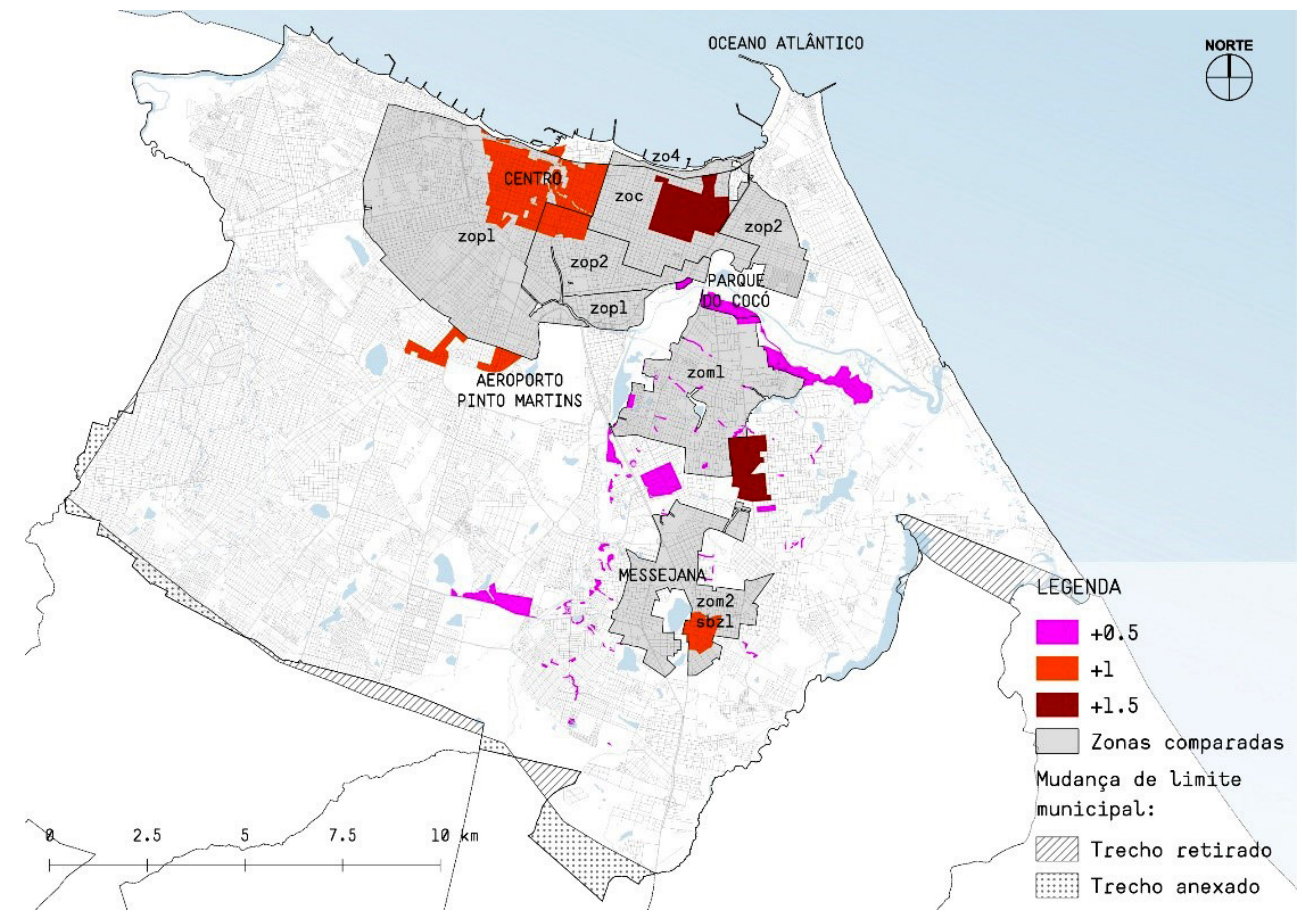

Fonte: organizado por Isabelle Almeida e Marcelo Capasso. Acervo LEHAB-UFC. 
Não abriram mão das limitações por mecanismos como o I.A.; elas foram simplesmente adaptadas a novas demandas. As alterações no zoneamento voltam-se a uma regulação para desregulamentação (tradução de regulated deregulation, de Aalbers, 2016), garantindo as condições de legitimidade à produção imobiliária de mercado, ao contrário de uma restrição eficiente contra transformações espaciais indesejadas.

In other words, under regulated deregulation some economic agents are given greater freedom from state control, but the market framework itself is regulated. In fact, the regulation of the market framework allows for the freedom of some economic agents within that framework (often at the expense of other agents). Regulated deregulation may appear a contradiction in terminis, but is intentionally so, an oxymoron, that breaks down the false dichotomy between regulation and deregulation. (Ibid., p. 3)

O I.A., a altura máxima e a fração do lote têm caráter de mecanismos coercitivos ("enforcement mechanisms", por Aalbers, 2016), limitando a construção de edifícios, e vêm sendo suficientemente ampliados para a atuação do mercado imobiliário em seus lugares estratégicos. Representam as negociações imobiliárias entre Estado e mercado, quantitativa e espacialmente, sujeitando o PDP a atualizações contraditórias. Biasotto e Oliveira (2011), ao tratar da difícil relação entre aplicação dos instrumentos de plano diretor e a regulação de potencial construtivo, ressaltam:

A incorporação de parâmetros urbanísticos na orientação da regulamentação do uso e ocupação do solo urbano é um diferencial importante dos planos diretores, sob o ponto de vista da sua aplicabilidade. [...] A possibilidade de manipulação do potencial construtivo fora dos planos diretores é um fator crítico para avaliação do alcance dos instrumentos previstos nos próprios planos. (p. 69; grifo nosso)

A incorporação dos parâmetros no plano diretor remonta ao importante avanço que chamamos de "antecipação do zoneamento". Quanto à avaliação do alcance dos planos, os autores ainda colocam o problema do potencial construtivo manipulado a posteriori, comprometendo a própria operacionalização dos objetivos. A manipulação deixa entrever o caráter eminentemente político da implementação do plano diretor e seu zoneamento, que não deveriam ser tomados como quadro de referência em soluções definitivas, dissociado do necessário controle social. No texto aprovado do PDP, havia a indicação de lei de conseIho municipal de desenvolvimento urbano, nos moldes do Conselho da Cidade, a ser regulamentado em até seis meses. Mas 2020 chegou sem esse instrumento paritário e deliberativo de participação popular, tendo a gestão continuado a se apoiar na CPPD.

Tanto as novas regulações de parâmetros quanto o negligenciamento do Conselho da Cidade coincidem com o esvaziamento da pauta progressista associada ao zoneamento especial. O PDP trazia em suas disposições finais a programação de regulamentação de ZEPH e de Lei de Habitação de Interesse Social (HIS) até 2010. O zoneamento especial para preservação cultural, por exemplo, apesar de não ter vindo de forma expressa no Estatuto na Cidade, remonta às recomendações da resolução n. 34 (2015) do Conselho das Cidades nacional, sobre o conteúdo mínimo de planos diretores. 
Isso motivou classificarmos as ZEPHs como de caráter progressista. Se regulamentadas, poderiam ter integrado incisivamente a política de preservação da gestão de uso e ocupação do solo, já que dariam parâmetros ao entorno de bens tombados, definindo de forma mais transparente como o potencial construtivo poderia ser utilizado. Mas sua delimitação e a extensão territorial no PDP, apesar de recobrir entorno de bens tombados ou classificados, já vieram com problemas. Dos 41 bens tombados (em nível federal, estadual ou municipal) até fins de 2008, apenas sobre 20 e seu entorno houve ZEPH delimitada no PDP. Além disso, das 6 ZEPHs instituídas no PDP, apenas 2, Centro e Parangaba, foram, à época, delimitadas em mapa, repetindo o equívoco do plano diretor anterior. Em 2020, temos apenas 1 delas normatizada com parâmetros, a Praia de Iracema, enquanto 3 sequer possuem delimitação: Benfica, Porangabuçu e Alagadiço-Novo.

Já a delimitação das zeis foi importante à breve inflexão do planejamento local a um "zoneamento de prioridades", pois, segundo Souza (2004, p. 262), "no que se refere aos investimentos públicos em infraestrutura, o Estado, em vez de favorecer os bairros já privilegiados, deveria pôr ênfase na satisfação das necessidades básicas dos mais pobres em matéria de equipamentos urbanos". No Congresso Popular de Aprovação do PDP (fevereiro de 2007), deliberativo, a escolha pelos delegados dos movimentos de seus grupos de trabalho refletia a importância atribuída às zeis: dos 47 representantes, 14 estavam no que tratava de zeis, sistema de mobilidade e parcelamento, uso e ocupação do solo; 12 , no de regularização fundiária; 11, no de sistema integrado de planejamento e gestão democráticos; e os 10 restantes distribuíram-se em três outros grupos.
Como resultado, Fortaleza tem 45 zeis1 (assentamentos precários), 56 zeis2 (loteamentos populares e conjuntos habitacionais sem titulação de posse) e 34 zeis3 (áreas com vazios urbanos), todas criadas no PDP, à exceção do Lagamar, de 2010. Das zeis1, 10 tiveram iniciados, em 2018, seus Planos Integrados de Regularização Fundiária (Pirf), a maioria, entretanto, com processos de elaboração estanques. Os Pirfs incluem diagnóstico, plano urbanístico, plano de regularização fundiária, plano de geração de trabalho e renda e plano de fortalecimento comunitário e desenvolvimento social, sendo uma conquista dos movimentos, ainda que tardia. Mais de uma década após a aprovação do PDP, a organização popular em torno do reconhecimento das zeis1 não arrefeceu. Em 2019, a luta contínua por sua regulamentação e elaboração dos Pirfs reflete a articulação dos movimentos sociais, na formação de um campo popular para controle social da revisão do PDP. Se houve ganhos, ainda que assimétricos, diante da gestão urbana, ao se constituírem os conselhos gestores das zeis e os Pirfs, eles se devem exatamente a essa conjunção popular de forças.

Maiores contrariedades sobre as zeis advêm da desregulamentação. A lei complementar n. 108 (2012) tornou "inválidas e sem eficácia", como zeis1, áreas vazias em seu interior, dificultando a regularização fundiária dos assentamentos precários. Porém, desregulamentação contraditória da política habitacional se deu já na aprovação do PDP, no artigo 312: primeiro, poder-se-ia ceder potencial construtivo dos lotes em áreas classificadas como zeis3 para outros locais; segundo, foi instituída a redução progressiva de zeis3, ao se permitir que, a cada ano, $5 \%$ da sua área total no Município fosse liberada "para a construção 
nos parâmetros da zona em que estão inseridas" (lei complementar n. 62, 2009), ou seja, negligenciando HIS. Ainda pelo dispositivo, desde 2013 todos os lotes em zeis3 podem ser dispensados de atender HIS, anulando possibilidades materiais de regulação do mercado para a promoção de inclusão socioterritorial. ${ }^{5}$ Associado a essa dinâmica, o maior indicador de falência da zeis3 foi o seu descompasso espacial com os empreendimentos do Programa Minha Casa Minha Vida, segregados nas bordas do município de Fortaleza (Pequeno e Rosa, 2016).
À parte dos Pirfs e da ZEPH Praia de Iracema, a implementação de zeis e ZEPH foi frustrada. Seu nível de sua regulação ficou muito aquém daquelas orientadas à ampliação de potencial construtivo. Como o zoneamento especial progressista atua tanto na permanência de população pobre quanto na preservação da unidade de paisagem dos bens tombados, caracteriza-se, também, como potencial empecilho à verticalização em áreas estratégicas para o mercado. Em Fortaleza, ainda é recorrente a remoção de população de assentamentos precários, inclusive tentativas em zeis1, como os

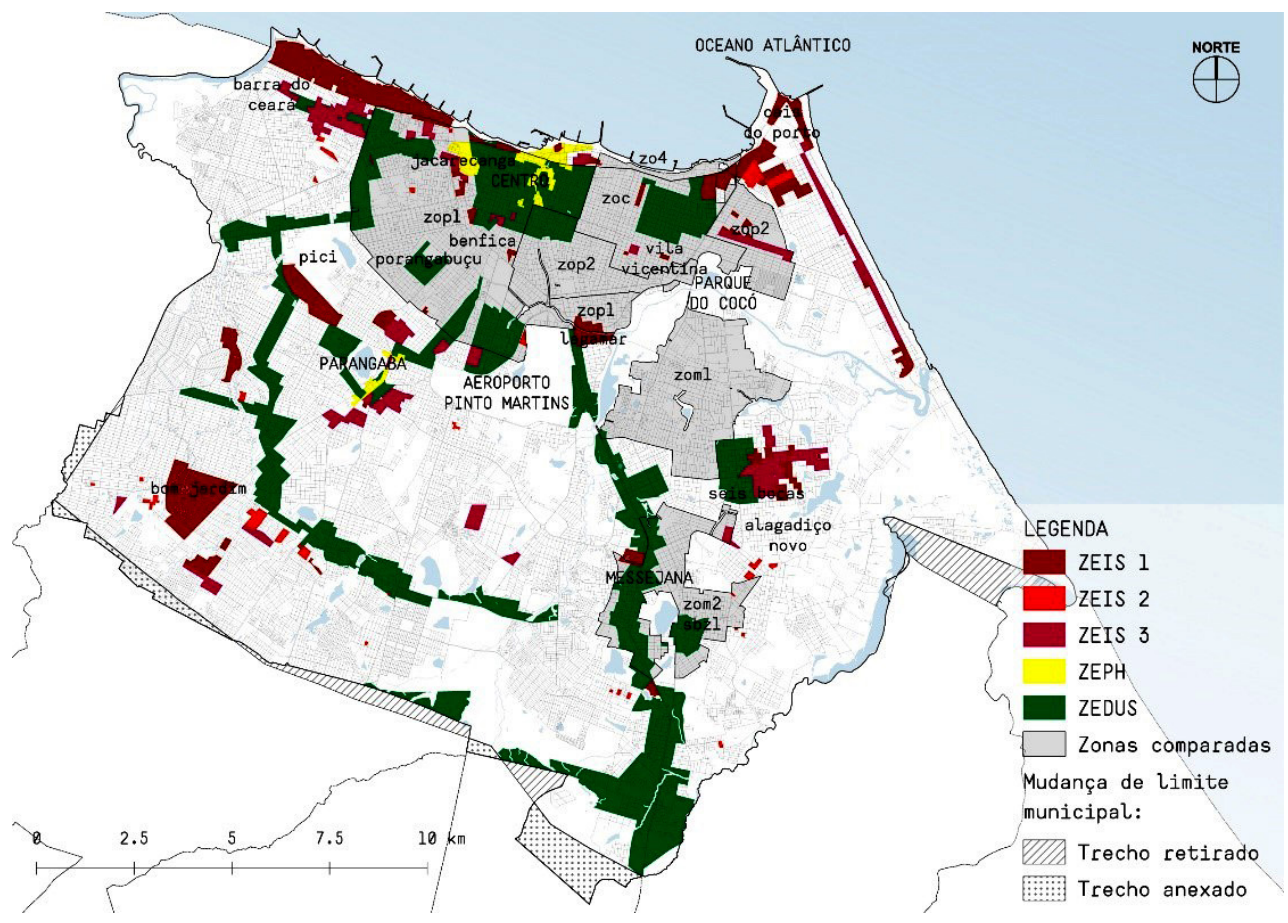

Fonte: organizado por Isabelle Almeida e Marcelo Capasso. Acervo LEHAB-UFC. 
recentes casos da Ocupação Salgadeira no Lagamar (ZOP1), Vila Vicentina da Estância (ZOC) e Comunidade do Farol no Cais do Porto (ZO6); da mesma forma, a aprovação de grandes empreendimentos verticais no entorno de bens tombados, como no Mercado dos Pinhões (ZOP1), na Igreja de São Pedro dos Pescadores (ZO4) e sobre o edifício São Pedro (ZO3). ${ }^{6}$ Une todos esses casos sua localização no principal vetor de verticalização intensiva do mercado imobiliário residencial, onde se agencia a maioria das alterações positivas de potencial construtivo, no recorte temporal aqui considerado - desde a discussão do PDP na Câmara Municipal.

A utilização de dispositivos regulatórios, como a zedus, além das várias emendas ao zoneamento, serviu, na prática, ao aumento generalizado do direito de construir e de sua outorga onerosa, o que, objetivamente, abriu maiores possibilidades à dispersão da verticalização.

Trataremos da relação espacial entre verticalização e alterações de I.A. no capítulo seguinte.

Quadro 2 - Implementação de zeis, ZEPH e zedus até 31/1/2020

\begin{tabular}{|c|c|c|c|c|}
\hline Zona & $\begin{array}{l}\text { Quantidade } \\
\text { instituída/ano }\end{array}$ & $\begin{array}{c}\text { Quantidade } \\
\text { delimitada/ano }\end{array}$ & $\begin{array}{c}\text { Quantidade } \\
\text { regulamentada/ano }\end{array}$ & Caracterização \\
\hline Zeis1 & $\begin{array}{c}45^{1} \\
\text { (44 em 2009; } \\
\text { Lagamar em 2010) }\end{array}$ & $\begin{array}{c}45 \\
\text { (44 em 2009; } \\
\text { Lagamar em 2010) }\end{array}$ & $\begin{array}{c}10 \\
\text { com Pirf iniciado } \\
(2018)\end{array}$ & $\begin{array}{l}\text { Assentamentos precários não } \\
\text { titulados }\end{array}$ \\
\hline Zeis2 & $\begin{array}{c}56^{1} \\
(2009)\end{array}$ & $\begin{array}{c}56 \\
(2009)\end{array}$ & 0 & $\begin{array}{l}\text { Loteamentos populares e } \\
\text { conjuntos habitacionais não } \\
\text { titulados }\end{array}$ \\
\hline Zeis3 & $\begin{array}{c}34^{1} \\
(2009)\end{array}$ & $\begin{array}{c}34 \\
(2009)\end{array}$ & 0 & Vazios urbanos destinados a HIS. \\
\hline ZEPH & $\begin{array}{c}7 \\
\text { (6 em 2009; } \\
\text { Jacarecanga em } \\
\text { 2017) }\end{array}$ & $\begin{array}{c}4 \\
\text { (Centro, } \\
\text { Parangaba: 2009; } \\
\text { Pr. de Iracema, } \\
\text { Jacarecanga: 2017) }\end{array}$ & $\begin{array}{c}1 \\
\text { (Praia de Iracema: } \\
\text { 2017) }\end{array}$ & $\begin{array}{l}\text { Entorno de bens tombados e } \\
\text { conjuntos de bens tombados e } \\
\text { classificados }\end{array}$ \\
\hline Zedus & $\begin{array}{c}23 \\
\text { (Centro, Francisco } \\
\text { Sá: 2009; } \\
23 \text { em 2017³) }\end{array}$ & $\begin{array}{l}\text { Todas foram } \\
\text { delimitadas quando } \\
\text { da instituição }\end{array}$ & $\begin{array}{c}23 \\
(2017)^{4}\end{array}$ & $\begin{array}{l}\text { Áreas para intensificação de } \\
\text { atividades sociais e econômicas, } \\
\text { garantindo sustentabilidade }\end{array}$ \\
\hline
\end{tabular}

(1) Fonte: PMF (2015).

(2) À ZEPH Praia de Iracema simplesmente foram atribuídos os parâmetros do trecho que recobre da ZO3. Foram definidos primeiro em 1995, restituídos em 2011 e novamente confirmados em 2017 por leis complementares.

(3) Francisco Sá e Centro têm delimitação pela lei complementar 236(2017); Centro foi, inclusive, dividido em dois trechos. Por isso, consideramos as Zedus Centro e Francisco de Sá na conta de 2017 novamente.

(4) Das 23 zedus regulamentadas em 2017, 10 aumentaram potencial construtivo sobre Zonas: Centro I e II, Aldeota, Varjota, Messejana, Montese, Vila União, Seis Bocas, Oliveira Paiva e Perimetral Sul. Outras 4, ao contrário, reduziram: BR-116 (III e IV), Perimetral Oeste e Anel Rodoviário II. As restantes são potencial "zoneamento de espera", caso haja futuras emendas a seus parâmetros. 


\section{A intensidade da verticalização - concentração e dispersão}

Na produção do espaço urbano brasileiro, a "forma vertical" costuma se apresentar concentrada em áreas estratégicas à captura de valor pelos agentes privados. A verticalização intensiva habitacional de alto padrão deixa ainda entrever outros processos espaciais, diametralmente opostos, como a formação de bolsões de vazios urbanos de espera e a segregação socioespacial involuntária da população mais pobre. Ao comentar os padrões de distribuição dos empreendimentos verticais, Souza (1994, p. 87) aponta que:
Os edifícios, no caso específico da verticalização, distribuem-se no solo através de formas quase sempre concentradas e que oferecem à observação empírica certas regularidades. Estas, por sua vez, apresentam certa constância no tempo, ao menos nas suas determinações mais gerais.

A verticalização é uma das dinâmicas mais elucidativas da valorização do solo urbano, pois ancora-se sobre áreas urbanas continuamente melhoradas por investimentos públicos e privados, como readequação da malha viária e construção de grandes equipamentos, retirando daí a regularidade temporal de sua localização.

Figura 5 - Intensidade relativa de verticalização "> que 15 pav." por Zona, de $1 / 4 / 2009$ a 31/12/2015, em Fortaleza

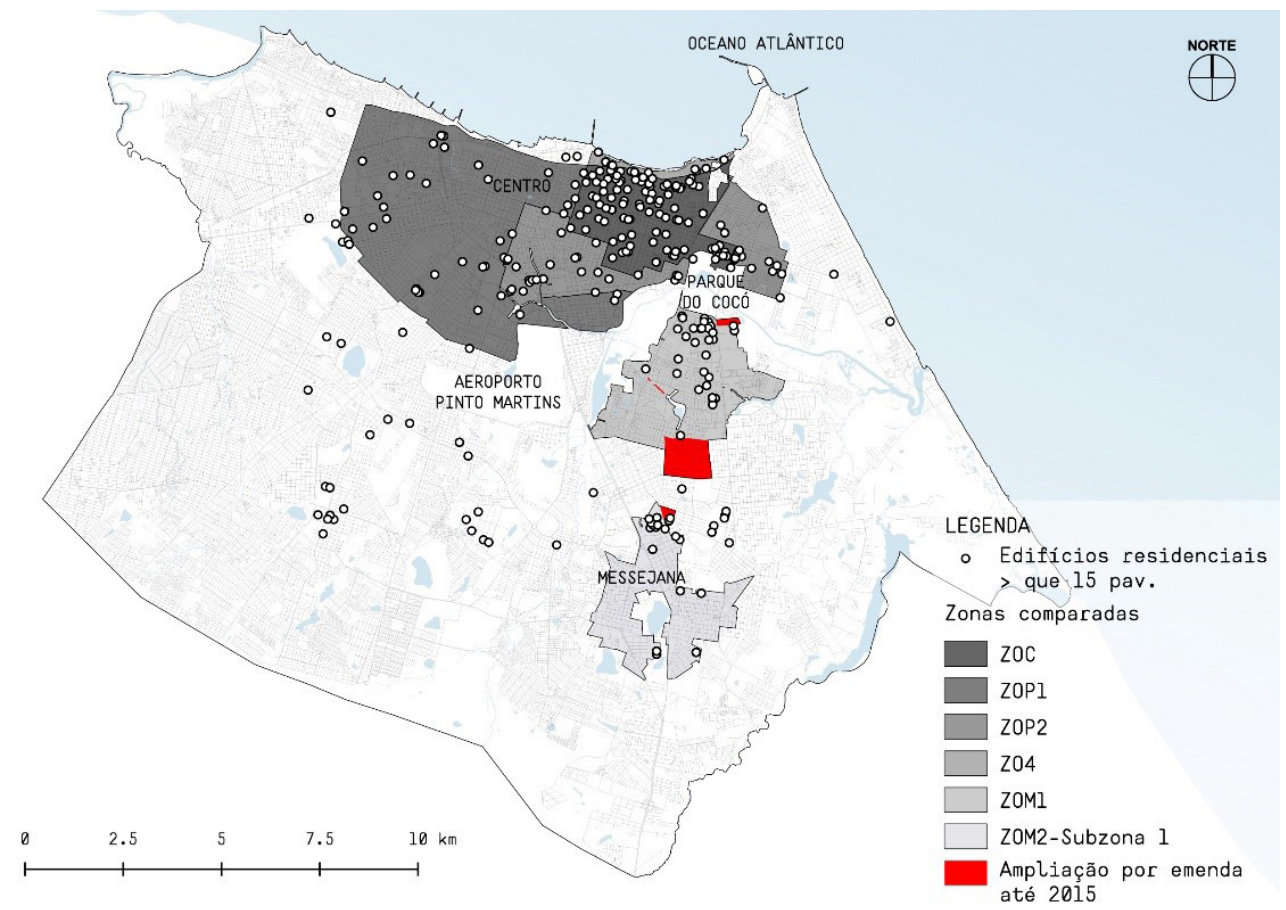

Fonte: organizado por Isabelle Almeida e Marcelo Capasso sobre dados do ITBI. SEFIN, 2016. Acervo LEHAB-UFC. 
Ao considerar as Zonas de Fortaleza que receberam maior aporte de coeficiente de outorga ou de direito de construir, constatou-se a forte correlação espacial com a verticalização de alto padrão intensiva. A maioria dos empreendimentos relacionados a apartamentos residenciais permaneceu na ZOC e na ZO4 (Meireles, Aldeota, Mucuripe), onde houve intensificação da verticalização desde a virada para a década de 1990. Além disso, na ZOP1, desde 2009, relativamente com menores limitações urbanísticas ao adensamento, houve o surgimento apenas incipiente de uma frente imobiliária de verticalização, em pontos dispersos ao redor do Centro (Parquelândia, São Gerardo, Benfica). Para visualizar a reconcentração da verticalização na ZOC e ZO4, assim como a dispersão em recortes espaciais igualmente concentrados (ZOM1 e ZOM2-Subz.1: Guararapes, Luciano Cavalcante, Parque Iracema), utilizamos dados do Imposto de Transmissão de Bens Imóveis - ITBI (Secretaria de Finanças de Fortaleza, 2016). Tomou-se, dessa forma, o tipo mais relevante para a escoIha dos recortes espaciais, o edifício vertical residencial com mais de 15 pavimentos (> que 15 pav.), com registro de construção de 1 을 de abril de 2009, início de vigência do PDP, a 31 de dezembro de 2015. Escolhemos o intervalo "> que 15 pav." por corresponder à altura máxima de 48 metros ou mais, cuja maioria dos casos, não por acaso, guarda coincidência espacial com a ZOC e a ZO4.

Comparando os empreendimentos residenciais "> que 15 pav.", utilizamos a área útil de cada Zona para balizar sua disponibilidade potencial de lotes e tornar o nível da concentração mais legível. Se utilizássemos apenas os números absolutos de empreendimentos, uma Zona de área exígua, como a ZO4 (74 ha), passaria completamente despercebida, não sendo possível vislumbrar o quão intensiva é sua verticalização. Na Tabela 1, mostra-se, assim, a intensidade de verticalização, considerando-se a área útil, de forma a tornar as Zonas espacialmente comparáveis.

A ZOC saiu na frente, com $37,71 \%$ de intensidade, contra 3,31\%, na ZOP1 (que tem 2539 ha, uma das maiores extensões do Município), e 10,81\% na ZOP2, mesmo que nestas últimas relativamente estivesse a menor limitação por I.A e altura máxima. A concentração de verticalização na ZOC foi pelo menos 11 vezes a da ZOP1 e 3,5 vezes a da ZOP2.

Já na ZO4 se produziu 29,55\% da intensidade de verticalização, quase 9 vezes a da ZOP1 e quase 3 vezes a da ZOP2. As ZOC e ZO4 possuem, juntas, 886 ha, correspondendo a apenas $2,76 \%$ da área municipal, mas concentraram em termos relativos, de 2009 a 2015, $67,26 \%$ da verticalização "> que 15 pav." de Fortaleza. Ou seja, uma superconcentração dos investimentos imobiliários privados.

A ZOM1 e a ZOM2-Subz.1 também apresentaram intensificação vertical significativa em relação ao restante do município. As ZOMs denominavam-se no PDDU-FOR como Zona Adensável, mas a carência de infraestrutura - não há sequer rede de esgoto consolidada - acabou direcionando sua reclassificação no PDP, impondo-se diversas restrições à ocupação em seus objetivos e parâmetros. Apesar disso, receberam juntas mais de 55 vezes a intensidade de verticalização da ZOP1 e quase 2 vezes à da ZOP2.

A criação das ZOPs, mesmo com os estímulos urbanísticos - e a maior disponibilidade de infraestrutura e transporte, segundo o PDP -, não foi capaz de reorientar para si o foco dos investimentos privados em verticalização. A maior intensidade de 
verticalização manteve-se, pelo contrário, exatamente no principal vetor de expansão imobiliária que vinha se consolidando desde o início da década de 1990, o Eixo Leste-Sudeste, estruturado pelas avenidas Santos Dumont e Washington Soares. Sua distribuição se manteve subordinada à estrita lógica mercantil, pelas melhores condições relativas de captura da valorização do solo. As atuais ZOC e a ZO4 remontam à principal área de verticalização residencial intensiva iniciada há cerca de 30 anos, com a grande maioria dos edifícios chegando aos 72 metros (24 andares), direcionada às classes A e B. Nos anos 2000, esse vetor de verticalização se ampliou para as atuais ZOM1 e ZOM2-Subz.1. O "salto" da mancha de verticalização "> que 15 pav." entre a ZOC-ZO4 e a ZOM1 deve-se a uma extensa área verde, 0 Parque do Cocó, mas que, pelo alto valor paisagístico, atrai verticalização no seu entorno. Já o "salto" entre a ZOM1 e a ZOM2 se deve ao cone aéreo do aeroporto Pinto Martins, que impede edifícios mais altos.

A ZO4, ZOC e ZOM1 têm, inclusive, o metro quadrado residencial de venda mais caro da cidade. Na série mensal de cinco bairros mais caros de Fortaleza, publicizada desde junho de 2016 pelo Índice Fipezap, figuram sempre Meireles (ZO4+ZOC), Mucuripe $(Z O 4+Z O C)$ e Guararapes (ZOM1). O valor de venda do metro quadrado nesses bairros, em janeiro de 2020, foi de, respectivamente, $R \$ 7.355,00, R \$ 6.952,00$ e $R \$ 6.724,00$ (Fipe, 2020). A constituição do vetor se deve ao fato

Tabela 1 - Intensidade da verticalização habitacional por Zona de Fortaleza (2009-2015)

\begin{tabular}{|c|c|c|c|}
\hline $\begin{array}{c}\text { Zonas } \\
\text { comparadas }\end{array}$ & $\begin{array}{l}\text { Qtde. e percentual } \\
\text { absolutos de imóveis } \\
\text { "> que } 15 \text { pav." na Zona }\end{array}$ & $\begin{array}{l}\text { Área útil da Zona } \\
\text { (ha) em } 2015\end{array}$ & $\begin{array}{l}\text { Intensidade relativa de verticalização: } \\
\text { percentual de imóveis "> que } 15 \text { pav." } \\
\text { proporcional à área útil da Zona }\end{array}$ \\
\hline ZOC & $\begin{array}{c}98 \\
42,2 \%\end{array}$ & 812 & $37,71 \%$ \\
\hline ZO4 & $\begin{array}{c}7 \\
3 \% \\
\end{array}$ & 74 & $29,55 \%$ \\
\hline ZOP2 & $\begin{array}{c}32 \\
13,8 \% \\
\end{array}$ & 926 & $10,81 \%$ \\
\hline ZOM2 - Subz.1 & $\begin{array}{c}24 \\
10,35 \% \\
\end{array}$ & 762 & $9,84 \%$ \\
\hline ZOM1 & $\begin{array}{c}26 \\
11,21 \% \\
\end{array}$ & 948 & $8,56 \%$ \\
\hline ZOP1 & $\begin{array}{c}27 \\
11,64 \% \\
\end{array}$ & 2539 & $3,31 \%$ \\
\hline Demais Zonas & $\begin{array}{c}18 \\
7,8 \%\end{array}$ & 25.938 & $0,22 \%$ \\
\hline Total & $\begin{array}{c}232 \\
100 \%\end{array}$ & 31.999 & $100,00 \%$ \\
\hline
\end{tabular}


de o Eixo Leste-Sudeste ter historicamente "atraído" equipamentos-chave para a valorização imobiliária. Desde pelo menos os anos 1970 o deslocamento das sedes institucionais de poder e a localização de grandes equipamentos provocaram o acentuamento de sua centralidade: a sede do executivo estadual e diversos shopping-centers na ZOC; a Universidade de Fortaleza, o Centro de Convenções do Ceará, o Fórum Clóvis Beviláqua, a Câmara Municipal e mais diversos shopping-centers na ZOM1; o centro administrativo do Ceará formado pelas secretarias de estado na ZOM2. A produção social do valor do solo vem sendo apropriada pelo mercado, consolidando o vetor ZO4+ZOC+ZOM1+ZOM2-Subz. 1 como o da autossegregação das classes A e B. De forma previsível, tiveram sua área útil expandida por emendas, até janeiro de 2020: a ZOM1, em 360 ha, sobre ZPRA, ZRA e ZOM2; a ZOM2-Subz.1, em 97 ha, sobre ZPA, ZRA e ZOM2. Assim, aumentaram I.A. bás., altura máxima e, junto ao Parque do Cocó, também coeficiente de outorga onerosa $(+0,5)$, em área da Macrozona de Proteção Ambiental rezoneada para ZOM2. Além disso, sobre a ZOC e a ZOM2, com a regulamentação de zedus, houve aumento do coeficiente de outorga onerosa da ordem de $+1,5$, na Aldeota e Varjota, $+1,5$, nas Seis Bocas, e +1 em Messejana.

Figura 6 - Variação do preço médio do $\mathrm{m}^{2}$ de venda de imóveis residenciais em janeiro de 2020, em Fortaleza

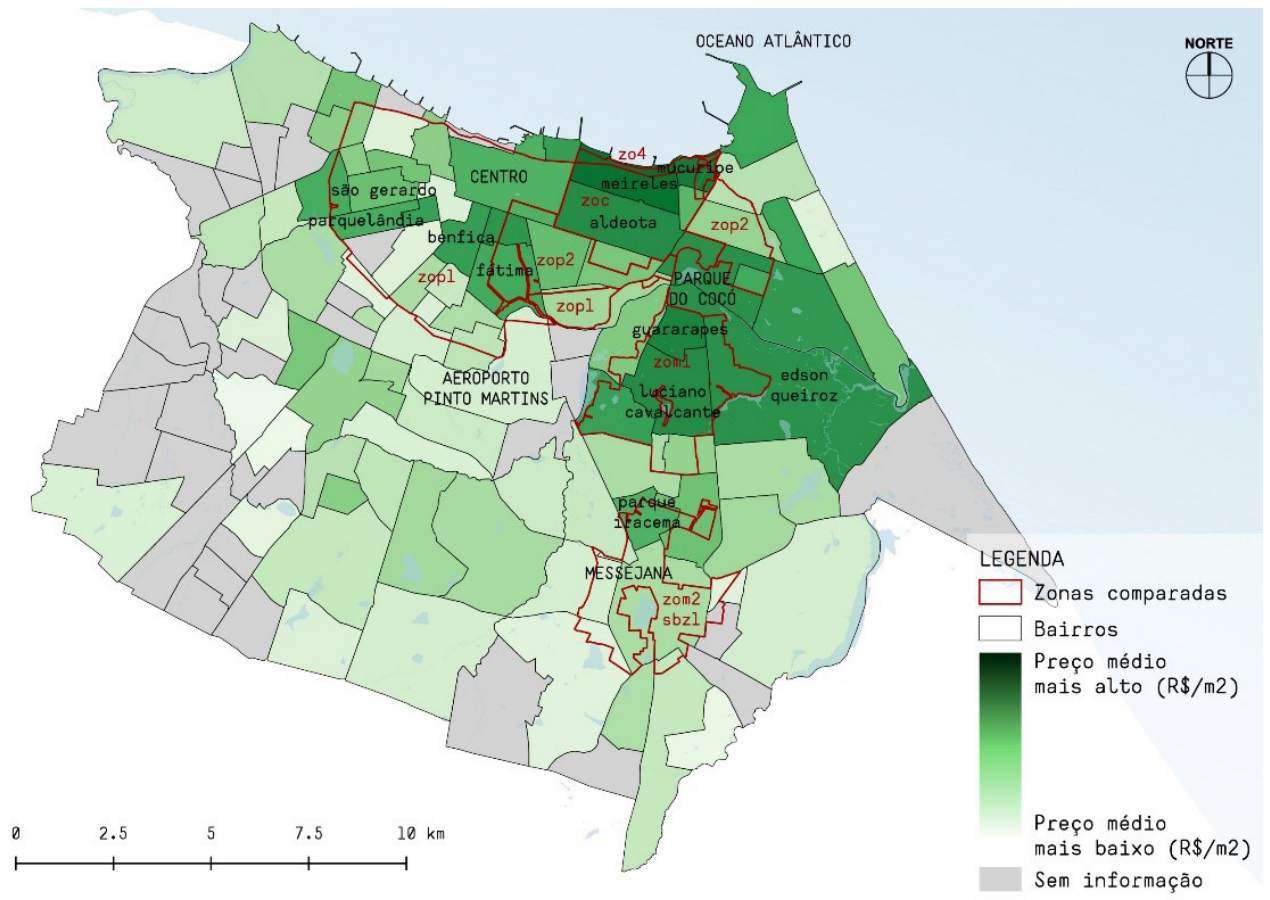

Fonte: organizado por Isabelle Almeida e Marcelo Capasso sobre mapa do Índice Fipezap. FIPE, 2020. Acervo LEHAB-UFC. 
$A$ intensidade da verticalização no vetor ZO4+ZOC+ZOM1+ZOM2-Subz.1 (85,66\%), superando em muito as ZOPs $(14,12 \%)$ - e contra o que havia disposto o PDP -, termina por ressaltar a captura de renda de monopólio da localização privilegiada, por meio da produção habitacional de alto padrão. As novas regulações de zoneamento refletem uma renovação dos históricos acordos entre Estado e produtores imobiliários, orientados à reversão do decréscimo da taxa de lucros de mercado.

Como a maioria das alterações de zoneamento do PDP ocorreram exatamente no período de crise do setor imobiliário, se reforça-se a hipótese de sujeição dos arranjos institucionais às demandas de mercado, consolidando o campo de forças em torno da implementação do PDP e da regulação do zoneamento a seu favor. A profunda alteração do marco regulatório veio apenas criar as condições de legitimidade para a inclinação da agenda urbana ao capital imobiliário. Os parâmetros são diferenciados dos princípios, como se se tratasse de duas coisas em separado, ressuscitando a contradição entre "plano" e "zoneamento" denunciada por Villaça (2005), além de pavimentar uma "nova ordem" ao planejamento, à mercê do etos neoliberal.

\section{Considerações finais}

O PDP respondeu às demandas atribuídas por uma agenda progressista? Apesar de ter assumido a dimensão simbólica de reversão da especulação imobiliária, de inclusão territorial dos mais pobres, de proteção aos bens tombados, seu alcance foi, na verdade, politicamente determinado. Para avaliar a questão, cabe trazer à luz a relação instrumental do plano com os grupos sociais, na forma como agenciam sua implementação. Desde a elaboração iniciada em 2002, de forma a se adaptar às novas questões postas pela promulgação do Estatuto da Cidade, o plano diretor de Fortaleza era indicador da ascendência da agenda progressista, com a ampliação da participação popular qualificada. A essa fase de alento se seguiram outras em que o campo de forças sofreu nova inclinação às demandas de mercado, em detrimento de princípios e objetivos socialmente acordados no plano.

Apesar de não serem revisões stricto sensu ao PDP, a constância nas emendas e outras fórmulas legais acabaram por ampliar a lacuna entre objetivos, de um lado, e, do outro, o conteúdo operacional, especificamente regulações de zoneamento. Como o plano é lei que impõe restrições e estímulos à produção formal do espaço urbano, seu controle político foi necessário para a consolidação da pauta de mercado e de seus interesses econômicos imediatos. A estagnação da regulação do Conselho da Cidade e a perpetuação da CPPD não são fatores isolados, apenas reforçando a situação a que chegamos em 2020, de controle da agenda urbana em favor do setor imobiliário. O recente anúncio de Operações Urbanas Consorciadas, espacialmente generalizadas, resultado do Programa Fortaleza Competitiva, veio, ainda, apontar o aprofundamento da regulação para desregulamentação.

As recentes notícias de conflitos em torno da revisão de planos diretores de cidades como Natal e Salvador, com proposta de ampliação generalizada da verticalização próximo a recursos de acentuado valor paisagístico, como o mar, são emblemáticas da retomada no planejamento urbano do paradigma mercantil, 
em detrimento da agenda progressista. Reconverter o marco regulatório urbanístico é condição sine qua non a um novo "ajuste urbano", com desdobramentos inéditos para as metrópoles litorâneas nordestinas, uma vez que consolidará a segregação socioespacial em nova escala, muito maior. A atual conjuntura política nacional já guarnece um novo ciclo de urbanização nas metrópoles brasileiras, rumo ao aprofundamento da racionalidade neoliberal, na medida em que despontam indicadores de financeirização na produção formal do espaço urbano, associados a uma menor intervenção estatal (Ribeiro, 2020).

É bastante sintomático que, em 2019, a criação de um núcleo gestor para a revisão do PDP - compartilhado com os movimentos sociais - apenas se deu após grande pressão popular. A articulação pelo Campo Popular do Plano Diretor tem se destacado nessa arena política, tomando a frente nas pautas populares. Entretanto, no debate já se reproduzem as condições de disputa pelo espaço urbano, à medida que os interesses dos diferentes agentes vêm assumindo legitimidade. A discussão em torno da revisão do PDP de Fortaleza, a prosseguir em 2021, inevitavelmente enfrentará maior consenso social em torno das pautas de mercado, em contexto político menos favorável à garantia do direito à cidade nas várias vertentes aqui discutidas, desde a regulamentação das zeis, até os instrumentos de preservação do patrimônio urbano.

Portanto, ao avaliar o alcance do PDP no seu decênio de vigência, observando as leis complementares e ordinárias que o regulamentaram, pode-se dizer que "funcionou" sim, mas sua figura de "plano-ação" tendeu às demandas regulatórias do mercado imobiliário. $A$ falência seletiva do plano diretor de Fortaleza coincidiu com a continuidade da exclusão territorial da população pobre, a redução paulatina de áreas de proteção ambiental e a ampliação do estoque imobiliário urbano subutilizado, resultando em retenção especulativa de terra urbana bem-localizada, novos desafios colocados à pesquisa socioespacial. A assimetria de conquistas na implementação do PDP revela o limite do instrumento. Não se pode tomá-lo dissociado da sociedade civil organizada que o produziu nem das pressões de agentes produtores do espaço com amplo controle sobre a gestão urbana, tampouco da capacidade de mobilização do instrumental do planejamento urbano em defesa ou detrimento dos mais diversos interesses, inclusive contraditórios.

\section{[I] https://orcid.org/0000-0003-4434-6778}

Universidade Federal do Ceará, Centro de Ciências, Departamento de Geografia, Programa de Pós-Graduação em Geografia. Fortaleza, CE/Brasil.

marcelocapasso@alu.ufc.br

\section{[II] https://orcid.org/0000-0003-2385-8440}

Universidade Federal do Ceará, Departamento de Arquitetura e Urbanismo e Design, Programa de Pós-Graduação em Arquitetura e Urbanismo e Design e em Geografia. Fortaleza, CE/Brasil.

renatopequeno@gmail.com 


\section{Notas}

(1) O primeiro processo de revisão do Plano Diretor de Fortaleza à luz do Estatuto da Cidade durou de 2002 a 2004 e teve como consultora a equipe da Associação Técnica Paulo de Frotin (Astef), locada na Universidade Federal do Ceará. Já o segundo processo, aberto em 2005, teve como equipe consultora o Instituto Pólis, de São Paulo.

(2) Utiliza-se, neste artigo, "Zona" em maiúscula ao se referir às subdivisões das Macrozonas do PDP 2009.

(3) Rufino (2016) apresenta em planta urbana as Zonas com parâmetros alterados, mas não informa a diferença de valores entre o projeto de lei e a lei promulgada do PDP.

(4) Quanto ao potencial construtivo adicional regulado por operações urbanas consorciadas em Fortaleza, Lage et al. (2018) tratam de sua espacialização e tipificação. Já, neste artigo, preferimos focar nas alterações de zoneamento stricto sensu.

(5) A dispensa de HIS em zeis3 foi uma regulação para desregulamentação de êxito em Fortaleza, não tendo sido sistematizado quantos lotes já foram utilizados para empreendimentos de mercado e sua distribuição no município.

(6) Um dos casos emblemáticos é o do edifício São Pedro (Iracema Plaza Hotel). Bem tombado provisoriamente pelo Conselho Municipal de Proteção do Patrimônio Histórico e Cultural de Fortaleza desde 2006, não foi incluído na ZEPH Praia de Iracema em 2017. Para a recuperação do edifício, parcialmente arruinado, há proposta, aprovada pela CPPD e com licença prévia expedida pela prefeitura de Fortaleza, de recuperação por meio de verticalização "sobre" ele, extrapolando limitações urbanísticas da ZO3-Subzona 1: o I.A. máx., atualmente idêntico ao I.A. básico, de 2 passará a 6,29, e a altura máxima, de $48 \mathrm{~m}$ a $9710 \mathrm{~m}$.

\section{Referências}

AALBERS, M. B. (2016). "Regulated deregulation". In: SPRINGER, S.; BIRCH, K.; MACLEAVY, J. (eds.). Handbook of Neoliberalism. Londres, Routledge. Disponível em: https://www.academia. edu/11365910/Regulated_Deregulation_chapter_in_Handbook_of_Neoliberalism. Acesso em: 2 jul 2020.

BIASOTTO, R.; OLIVEIRA, F. L. de (2011). "O acesso à terra urbana urbanizada nos planos diretores brasileiros". In: MONTADON, D. T.; SANTOS JUNIOR, O. A. dos (orgs.). Os planos diretores municipais pós-Estatuto da Cidade: balanço crítico e perspectivas. Rio de Janeiro, Letra Capital.

BRASIL (2008). Estatuto da Cidade. Brasília, Senado Federal, Subsecretaria de Edições Técnicas. Disponível em: https://www2.senado.leg.br/bdsf/bitstream/handle/id/70317/000070317. pdf?sequence $=6 \% 20$ Calizaya. Acesso em: 2 jul 2020. 
BRASIL, A.; CAPASSO, M. M.; CAVALCANTI, E. (2017). A mercantilização do espaço urbano em Fortaleza: instrumentos urbanísticos como meio de promoção de negócios imobiliários em detrimento da democratização do espaço urbano. In: XVII ENCONTRO NACIONAL DA ANPUR DESENVOLVIMENTO, CRISE E RESISTÊNCIA: QUAIS OS CAMINHOS DO PLANEJAMENTO URBANO E REGIONAL? Anais... São Paulo, Enanpur. Disponível em: http://anpur.org.br/xviienanpur/ principal/publicacoes/XVII.ENANPUR_Anais/ST_Sessoes_Tematicas/ST\%203/ST\%203.4/ST\%20 3.4-01.pdf. Acesso em: 2 jul 2020.

CASTILHO, J. R. F. (2010). Disciplina urbanística da propriedade: o lote e seu destino. São Paulo, Pillares.

CULLINGWORTH, J. B. (2005). The political culture of planning. American land use planning in comparative perspective. Nova York e Londres, Routledge.

FIPE - Fundação Instituto de Pesquisas Econômicas (2020). Fipezap: índice de preços de imóveis anunciados - venda residencial. Disponível em: https://www.fipe.org.br/pt-br/publicacoes/ relatorios/\#relatorio-fipezap\&fipezap. Acesso em: 2 jul 2020.

FREITAS, C. F. S.; PEQUENO, R. (2012). Desafios para a implementação de Zonas Especiais de Interesse Social em Fortaleza. Cadernos Metrópole. São Paulo, v. 14, n. 28, pp. 485-505. Disponível em: http://revistas.pucsp.br/metropole/article/view/14819/10809. Acesso em: 2 jul 2020.

GOMES, M. P. C. (2006). O plano diretor de desenvolvimento urbano - após o Estatuto da Cidade. Rio de Janeiro, s.e. Disponível em: https://www.cidades.ce.gov.br/wp-content/uploads/ sites/12/2013/01/Plano_Diretor_Desenvolvimento_Urbano.pdf. Acesso em: 2 jul 2020.

LAGE, M.; LIMA, P.; NASSIF, T.; PEQUENO, L. R. B.; ROSA, S. V. (2018). “Regulação para desregulamentação: novos e velhos instrumentos urbanísticos". In: ROLNIK, R.; SANTORO, P. F.; NASCIMENTO, D. M.; FREITAS, D. M.; RENA, N. S. A.; PEQUENO, L. R. B. (orgs.). Cidade Estado Capital: reestruturação urbana e resistências em Belo Horizonte, Fortaleza e São Paulo. São Paulo, FAU-USP. Disponível em: https://observasp.files.wordpress.com/2018/04/cidadestadocapital_virt_low.pdf. Acesso em: 26 jun 2020.

Lei complementar n. 62 de 2 de fevereiro de 2009 (2009, 13 março). Plano Diretor Participativo. Diário Oficial do Município. Fortaleza, CE, ano LVI, n. 14.020.

Lei complementar n. 79 de 7 de maio de 2010 (2010, 13 maio). Diário Oficial do Município. Fortaleza, CE, ano LVII, n. 14.301.

Lei complementar n. 101 de 30 de dezembro de 2011 (2012, 20 novembro). Diário Oficial do Município. Fortaleza, CE, ano LX, n. 14.919.

Lei complementar n. 108 de 30 de maio de 2012 (2012, 14 junho). Diário Oficial do Município. Fortaleza, CE, ano LX, n. 14.812 .

Lei complementar n. 142 de 14 de março de 2013 (2013, 15 março). Diário Oficial do Município. Fortaleza, CE, ano LX, n. 14.997.

Lei complementar n. 202 de 13 de maio de 2015 (2015, 18 maio). Diário Oficial do Município. Fortaleza, CE, ano LXI, n. 15.523.

Lei complementar n. 236, de 11 de agosto de 2017 (2017, 11 agosto). Lei de Parcelamento, Uso e Ocupação do Solo. Diário Oficial do Município. Fortaleza, CE, ano LXIII, n. 16.078.

Lei complementar n. 243, de 21 de dezembro de 2017 (2017, 29 dezembro). Diário Oficial do Município. Fortaleza, CE, ano LXIII, n. 16.171. 
Lei complementar n. 250, de 3 de julho de 2018 (2018, 12 julho). Diário Oficial do Município. Fortaleza, CE, ano LXIV, n. 16.299.

Lei complementar n. 277, de 23 de dezembro de 2019 (2019, 27 dezembro). Diário Oficial do Município. Fortaleza, CE, ano LXV.

Lei complementar n. 281, de 23 de dezembro de 2019 (2019, 27 dezembro). Diário Oficial do Município. Fortaleza, CE, ano LXV, n. 16.658.

Lei complementar n. 282, de 23 de dezembro de 2019 (2019, 27 dezembro). Diário Oficial do Município. Fortaleza, CE, ano LXV, n. 16.658.

Lei complementar n. 285, de 27 de dezembro de 2019 (2019, 30 dezembro). Diário Oficial do Município. Fortaleza, CE, ano LXV, n. 16.659.

Lei complementar n. 287, de 6 de janeiro de 2020 (2020, 24 janeiro). Diário Oficial do Município. Fortaleza, CE, ano LXVI, n. 16.676.

Lei n. 7.061, de 16 de janeiro de 1992 (1992). Plano Diretor de Desenvolvimento Urbano. Fortaleza, CE. Disponível em: https://urbanismoemeioambiente.fortaleza.ce.gov.br/images/urbanismo-emeio-ambiente/servicos/PDDUFOR---1992.pdf. Acesso em: 2 jul 2020.

Lei n. 7.987, de 23 de dezembro de 1996 (2010). Lei de Uso e Ocupação do Solo, consolidada em setembro de 2006, atualizada em agosto de 2010, contendo as Leis de alteração e Decretos de regulamentação de novas atividades. Fortaleza, CE. Disponível em: https:// urbanismoemeioambiente.fortaleza.ce.gov.br/images/urbanismo-e-meio-ambiente/legislacaomunicipal/lei_complementar_n_7_987_de_23_de_dezembro_de_1996_consolidada_em_ setembro_de_2006.pdf. Acesso em: 2 jul 2020.

Lei ordinária n. 10.335, de 1o de abril de 2015 (2015, 9 abril). Diário Oficial do Município. Fortaleza, CE, ano LXI, n. 15.499.

Lei ordinária n. 10.431, de 22 de dezembro de 2015 (2015, 30 dezembro). Diário Oficial do Município. Fortaleza, CE, ano LXI, n. 15.678.

MEIRELLES, H. L. (2008). Direito Municipal. São Paulo, Malheiros.

PEQUENO, R.; ROSA, S. V. (2016). O Programa Minha Casa Minha Vida na Região Metropolitana de Fortaleza-CE: análise dos arranjos institucionais. Cadernos Metrópole. São Paulo, v. 18, n. 35, pp. 191-216. Disponível em: https://revistas.pucsp.br/metropole/article/ view/2236-9996.2016-3509/19153. Acesso em: 2 jul 2020.

PMF - PREFEITURA MUNICIPAL DE FORTALEZA (2015). Relatório das zeis. Fortaleza, Instituto de Planejamento de Fortaleza. Disponível em: https://fortaleza2040.fortaleza.ce.gov.br/site/assets/ files/publications/fortaleza2040_relatorio-das-zeis_14-10-2016.pdf. Acesso em: 2 jul 2020.

RESOLUÇÃO n. 34, de 1o de julho de 2005 (2005, 14 julho). Diário Oficial da União. Brasília, DF, ano CXLII, n. 134, p. 89. Disponível em: http://pesquisa.in.gov.br/imprensa/jsp/visualiza/index.jsp?d ata=14/07/2005\&jornal=1\&pagina=89\&totalArquivos=184. Acesso em: 2 jul 2020.

RIBEIRO, L. C. Q. (2020). “Inflexão ultraliberal e a financeirização da ordem urbana brasileira: explorando algumas hipóteses”. In: RIBEIRO, L. C. Q. (org.). As metrópoles e o capitalismo financeirizado. Rio de Janeiro, Letra Capital e Observatório das Metrópoles.

RUFINO, B. (2016). Incorporação da metrópole: transformações na produção imobiliária e do espaço na Fortaleza do século XXI. São Paulo, Annablume. 
SECRETARIA DE FINANÇAS DE FORTALEZA - Sefin (2016). Imposto de Transmissão de Bens Imóveis (ITBI) [Banco de Dados].

SOUZA, M. L. (2004). Mudar a cidade: uma introdução crítica ao planeamento e à gestão urbanos. Rio de Janeiro, Bertrand Brasil.

SOUZA, M. A. A. (1994). A identidade da metrópole: a verticalização em São Paulo. São Paulo, Hucitec e Edusp.

VILLAÇA, F. (2005). As ilusões do plano diretor. São Paulo, Edição do autor. Disponível em: http:// docplayer.com.br/3158493-Flavio-villaca-as-ilusoes-do-plano-diretor.html. Acesso em: 2 jul 2020.

Texto recebido em $14 /$ jul/2020

Texto aprovado em 20/out/2020 